\title{
THE COPENHAGEN ACCORD AND THE FUTURE OF THE INTERNATIONAL CLIMATE CHANGE REGIME
}

\author{
FRANCESCO SINDICO \\ Lecturer \\ University of Surrey (Guildford, UK) \\ Deputy Director \\ Environmental Regulatory Research Group \\ f.sindico@surrey.ac.uk
}

\begin{abstract}
This paper analyses the environmental integrity, the nature and the political relevance of the Copenhagen Accord. According to the first two parameters, the Copenhagen Accord is not satisfactory. From a political point of view the conclusion is slightly different, albeit not positive. This paper concludes arguing that after the Copenhagen Conference the future of the international climate change legal regime is likely to be more fragmented, the Accord being one further piece of the global carbon puzzle.
\end{abstract}

RESUM: Aquesta nota analitza la integritat ambiental, la natura i la rellevança política de l'Acord de Copenhaguen. D'acord amb els dos primers paràmetres, l'Acord de Copenhaguen no és satisfactori. Des del punt de vista polític, tanmateix, la conclusió és lleugerament diferent, tot i que no positiva. Aquesta nota conclou defensant que, després de l'Acord de Copenhaguen, el futur del règim jurídic internacional del canvi climàtic serà, previsiblement, més fragmentat, essent l'Acord una peça més dintre del trencaclosques global del carboni. 
RESUMEN: Esta nota analiza la integridad ambiental, la naturaleza y la relevancia política del Acuerdo de Copenhague. De acuerdo con los dos primeros parámetros, el Acuerdo de Copenhague no es satisfactorio. Desde el punto de vista político, sin embargo, la conclusión es ligeramente diferente, aunque no positiva. Esta nota concluye defendiendo que, después del Acuerdo de Copenhague, el futuro del régimen jurídico internacional del cambio climático será, previsiblemente, más fragmentado, siendo el Acuerdo una pieza más dentro del rompecabezas global del carbono.

KEYWORDS: Copenhagen Accord — climate change — Kyoto Protocol

PARAULES CLAU: Acord de Copenhaguen - canvi climàtic - Protocol de Kyoto

PALABRAS CLAVE: Acuerdo de Copenhague — cambio climático — Protocolo de Kyoto

Summary: I. Introduction; II. The Copenhagen Accord. 1. The environmental integrity of the Copenhagen Accord. 2. The nature of the Copenhagen Accord. 3. The political relevance of the Copenhagen Accord. III. Conclusions: The Copenhagen Accord and the fragmentation of the international climate change regime. IV. Bibliography. Annex I: The Copenhagen Accord. Annex II: Quantified economy-wide emissions targets for 2020. Annex III: Nationally appropriate mitigation actions of developing country Parties.

\section{INTRODUCTION}

The fifteenth Conference of the Parties (COP) of the United Nations Framework Convention on Climate Change (UNFCCC) and the fifth Meeting of the Parties (COP/MOP) of the Kyoto Protocol took place in Copenhagen from 7 to 18 December 2009. More than 50.000 participants were accredited and 120 Heads of State and Governments participated in the high level segment making the Copenhagen Conference the highest profile meeting of any multilateral environmental agreement. In this paper I will focus only on the Copenhagen Accord and, in particular, on how it deals with mitigation. I will assess 
it from an environmental, legal and political point of view in order to draw some conclusions on the future of the international climate change regime ${ }^{1}$

\section{THE COPENHAGEN ACCORD}

International climate change negotiations have followed two parallel tracks in the last years: one under the UNFCCC and the other under the Kyoto Protocol. The first track was launched in Bali, at the thirteenth COP of the UNFCCC, and countries were meant to devise ways to achieve "full, effective and sustained implementation of the Convention through long-term cooperative action, now, up to and beyond 2012",2. Under the second track countries have been negotiating ways to enhance further Kyoto Protocol Annex I Parties' obligations ${ }^{3}$.

Both tracks should have ended at the Copenhagen Conference, but it was clear in the meetings prior to COP15 and COP/MOP5 that this would not be achieved ${ }^{4}$. While some countries, and the EU in particular, were aiming for a new legally binding international treaty, still there was hope to be able to secure, at least, a range of COP decisions that would have been able to guide the negotiations further in the aftermath of Copenhagen. These hopes were also frustrated when, at the end of the two weeks of negotiations, a rather small (albeit influential) group of countries was able to broker the Copenhagen Accord, which is not a COP decision. Decision -/CP.15 "takes note of the Copenhagen Accord".

\footnotetext{
${ }^{1}$ In this brief I will not be providing a complete analysis of the negotiations that have taken place during the two weeks in Copenhagen. For a detailed study of the latter see WEMAËRE M., "State of play of the international climate change negotiations: what are the results of the Copenhagen Conference?", Carbon and Climate Law Review, no. 4.1, 2010, pp. 106-111; DUBASH N.K., "Copenhagen: Climate of Mistrust", Economic and Political Weekly, no. 52, 2009, pp. 8-11. Nor will I focus on how the Copenhagen Accord deals with adaptation, reducing emission from deforestation and forest degradation (REDD) and finance, which feature prominently in the document; see $\S 3$ for adaptation, $\S 6$ for REDD; $\S 8$ for finance, including the establishment of a High Level Panel and of the Copenhagen Green Climate Fund, respectively at $\S 9$ and 10.

${ }^{2}$ Decision 1/CP.13, Bali Action Plan, § 1. The Ad-Hoc Working Group on Long-term Cooperative Action (AWG-LCA) has been in charge of negotiations under this track.

${ }^{3}$ The Ad Hoc Working Group on Future Commitments for Annex I Parties under the Kyoto Protocol (AWG$\mathrm{KP}$ ) has been in charge of negotiations under this track.

${ }^{4}$ See an analysis of the 2009 talks in Bangkok and in Barcelona in WEMAËRE M., "State of Play of International Negotiations: On the Road to Copenhagen" in Carbon and Climate Law Review, no. 3.4, 2009, pp. $497-502$
} 
I will now move on and assess the Copenhagen Accord from an environmental, legal and political parameter in order to determine whether the outcomes of the talks in Copenhagen can be hailed as a success or a failure.

\section{The environmental integrity of the Copenhagen Accord}

For an international regime to properly tackle climate change it needs to meet the final objective of the UNFCCC, which is to prevent dangerous climate change ${ }^{5}$. According to most scientific reports an overall increase in the world's temperature above 1.5 degrees will lead to dangerous climate change. The Intergovernmental Panel on Climate Change (IPCC) has suggested in its Fourth Assessment Report that a reduction in the range of 25 to $40 \%$ from 1990 levels is needed in order to avoid this ${ }^{6}$. Does the Copenhagen Accord set this environmental target and does it provide the necessary tools to achieve it?

The answer is no. On the one hand, the goal of the States that have affiliated themselves to the Copenhagen Accord is not to limit the overall temperature increase to 1.5 degrees, but "to hold the increase in global temperature below 2 degrees Celsius"7. One has to acknowledge that countries were aware that "deep cuts in global emissions are required according to science", 8 but no mention of specific cuts has been included in the Copenhagen Accord. Furthermore, by making an explicit reference to the need for revising the Copenhagen Accord in 2015 in order to consider ways to achieve a maximum increase of 1.5 degrees $^{9}$, the document shows a current lack of ambition from an environmental perspective. In sum, contrary to the Kyoto Protocol where a specific cap was established

\footnotetext{
${ }^{5}$ United Nations Framework Convention on Climate Change (adopted 9 May 1992, entered into force 21 March 1994) (1992), 31 ILM 822, art. 2: "The ultimate objective of this Convention and any related legal instruments that the Conference of the Parties may adopt is to achieve, in accordance with the relevant provisions of the Convention, stabilization of greenhouse gas concentrations in the atmosphere at a level that would prevent dangerous anthropogenic interference with the climate system. Such a level should be achieved within a time-frame sufficient to allow ecosystems to adapt naturally to climate change, to ensure that food production is not threatened and to enable economic development to proceed in a sustainable manner."

${ }^{6}$ PACHAURI R.K. and RESINGER A. (Eds.), IPCC Fourth Assessment Report, Climate Change 2007 Synthesis Report, Contribution of Working Groups I, II and III to the Fourth Assessment Report of the Intergovernmental Panel on Climate Change, Geneva, 2007. Accessed on 15/04/10, at http://www.ipcc.ch/pdf/assessment-report/ar4/syr/ar4_syr.pdf.

${ }^{7}$ Copenhagen Accord, $\S 2$.

${ }^{8}$ Ibid.

${ }^{9}$ Ibid. $\S 12$.
} 
$(5 \% \text { reduction from } 1990 \text { levels })^{10}$, the Copenhagen Accord refers very loosely to reductions in emissions necessary to avoid a 2.0 degree increase in overall temperatures taking into account the general objective of the UNFCCC, but it does not establish any specific cap.

On the other hand, the Copenhagen Accord has created a bottom up approach to mitigate climate change. The Kyoto Protocol not only established a general cap, baseline and base year, but it also indicated how much each Annex I Party had to reduce in the 2008-2012 commitment period $^{11}$. The Copenhagen Accord enshrines a much more flexible approach in as far as it gives each State, both industrialized and developing, the possibility to decide its level of climate change mitigation ambition ${ }^{12}$. This bottom up approach is the content of the so called "pledges" that all countries that decide to affiliate themselves to the Copenhagen Accord were asked to submit to the UNFCCC Secretariat by 31 January $2010^{13}$. Annexes II and III of this article include excerpts of the pledges from key States, whose action in relation to climate change mitigation will be critical to tackle climate change efficiently.

Leaving aside for the moment the nature of these pledges, the environmental integrity of a regime based on the Copenhagen Accord would depend on whether the compliance with the emissions reductions level provided for in the pledges would actually limit an overall increase in temperatures to 2.0 degrees (or even better, 1.5 degrees). This does not seem to be the case. On the one hand, the first analysis of the pledges shows that, even if they were complied with, they would not deliver the necessary emission reductions needed to avoid dangerous climate change ${ }^{14}$. On the other hand, most of these pledges are conditional on

\footnotetext{
${ }^{10}$ Kyoto Protocol to the 1992 Framework Convention on Climate Change (adopted 10 December 1997) (1998) 37 ILM 22, art. 3.1

${ }^{11}$ Ibid., Annex B.

${ }^{12}$ Thereby one country can decide to use, for example, 1990 as base year, while another can adopt 2005 for the same purpose. One country highly committed to mitigating climate change may decide for a $30 \%$ reduction, while another country may decide for a much less ambitious target. Finally, one country may decide to reduce on a historical basis following the methodology provided for in the Kyoto Protocol, while another one can decide to reduce emissions based on a per capita, or per gross national product basis. See different examples in the pledges from industrialised and developing countries in Annex II and III.

${ }^{13}$ Copenhagen Accord, $\S 4$ and 5.

${ }^{14}$ See LEVIN K. and BRADLEY R., "Comparability of Annex I Emission Reduction Pledges," WRI Working Paper, World Resources Institute, Washington DC, p. 2. Accessed on 15/04/10, at | http://www.wri.org.
} 
similar climate change mitigation action taken by other countries, as is the case of the $\mathrm{EU}^{15}$, or, as in the case of the Russian federation and South Africa ${ }^{16}$, conditional on the nature of future emission reduction obligations.

This last point leads us to assess the nature of the obligations provided for in the Copenhagen Accord in order to determine whether they can be considered to be legally binding or just recommendatory.

\section{The nature of the Copenhagen Accord}

While having a legally binding international treaty does not mean per se that the environmental problem dealt therewith will definitely be solved, hard law does usually have at least two characteristics that enable countries to tackle efficiently an environmental problem. On the one hand, a legally binding instrument will have enforceable obligations that are binding upon State Parties and, on the other hand, it will have a compliance system that will establish a mechanism that will address situations of non-compliance. Does the Copenhagen Accord, despite its environmental pitfalls, have clear cut obligations and a strong compliance system?

Once again the answer is no. On the one hand, the system of pledges provided for in the Copenhagen Accord both for industrialized and emerging developing countries is, as we have seen, a bottom up approach where States are free to decide their level of ambition in relation to climate mitigation. Furthermore, and this is clear from the text of the pledges themselves, the nature of the obligation to which they are committing themselves is voluntary, not binding. In particular, developing countries, such as China, made it very clear that they do not consider themselves legally bound by their pledges ${ }^{17}$.

\footnotetext{
${ }^{15}$ An example of this approach comes from the EU that has committed itself to a unilateral $20 \%$ reduction from 1990 levels by 2020, which would increase to a 30\% reduction if "other developed countries commit themselves to comparable emission reductions and that developing countries contribute adequately according to their responsibilities and respective capabilities"; see EU pledge in Annex II of this brief. See also the 28 January 2010 Press Release 57/62 for the EU pledge.

${ }^{16}$ See Annex II and III of this paper.

${ }^{17}$ See China's pledge in Annex III: "Please note that the above-mentioned autonomous domestic mitigation actions are voluntary in nature."
} 
On the other hand, the Copenhagen Accord does not mention the compliance system provided for in the Kyoto Protocol ${ }^{18}$, which has been hailed as one of the most advanced of any MEA. ${ }^{19}$ The Enforcement Branch of the latter has the power to take measures against countries found in non compliance with their obligations under the Kyoto Protocol ${ }^{20}$. In the Copenhagen Accord "compliance" becomes "measurement, report and verification (MRV)", which seems to be structured in three different ways depending on whose mitigation action is considered. First, climate change mitigation action enshrined in pledges from Annex I countries will be "measured, reported and verified in accordance with existing and any further guidelines adopted by the Conference of the Parties"21. Second, mitigation action undertaken by developing countries will be subject to domestically established MRV. The Copenhagen Accord states as follows: "[M]itigation actions taken by Non-Annex I Parties will be subject to their domestic measurement, reporting and verification the result of which will be reported through their national communications every two years" ${ }^{22}$. Finally, non Annex I countries can also decide to adopt mitigation action, which will be supported by international assistance. In this third instance the Copenhagen Accord establishes that: "[T] hese supported nationally appropriate mitigation actions will be subject to international measurement, reporting and verification in accordance with guidelines adopted by the Conference of the Parties"23.

Two comments can be made on the MRV system provided for in the Copenhagen Accord. On the one hand, both for mitigation action taken by Annex I countries and for supported climate change mitigation action by Non Annex I countries the system requires further development through the COP. In other words, the system, as it currently stands, is not "operational immediately", despite what is stated in the preamble to the Copenhagen Accord... On the other hand, it is not clear what kind of consequences may arise if

\footnotetext{
${ }^{18}$ Kyoto Protocol, art. 18 and Decision 27/CP.7, Procedures and mechanisms relating to compliance under the Kyoto Protocol.

${ }^{19}$ On the Kyoto compliance system see, amongst others, CAMPINS ERITJA M., FERNÁNDEZ PONS X. and HUICI SANCHO L., "Compliance Mechanisms in the Framework Convention on Climate Change and the Kyoto Protocol", Revue Générale de Droit, no. 34.1, 2004, pp. 51-105.

${ }^{20}$ Decision 27/CP.7, Section V, § 6.

${ }^{21}$ Copenhagen Accord, $\S 4$.

${ }^{22}$ Ibid., $\S 5$. Emphasis added.

${ }^{23}$ Ibid., § 5 .
} 
countries, in particular developing countries, do not comply with their pledges. Firstly, these are voluntary in nature, therefore not binding. Secondly, they will be subject to "domestic" MRV. It is arguably unlikely to see a State adopting "serious consequences", using the Kyoto Protocol terminology, against itself for an alleged non compliance with voluntary climate mitigation targets...

These observations on the nature of the obligations provided for in the Copenhagen Accord, and on its MRV system, lead to the conclusion that we are before a soft law document, whose obligations are not binding. This conclusion will be disappointing for civil society members and those countries that prior to the Copenhagen conference were aiming for a legally binding treaty (hard law) that would either replace the Kyoto Protocol, or stand beside it.

Not only can one find problems regarding the nature of the obligations present in the Copenhagen Accord; most commentators are also puzzled about the nature of the Copenhagen Accord per se. The latter is not a COP decision, albeit a COP decision "takes note" of it, which is a novelty within the international climate change regime ${ }^{24}$. It is also not an international treaty, according to the rules provided for in the Vienna Convention on the Law of Treaties ${ }^{25}$. I agree with Matthieu Wemaëre in maintaining that the Copenhagen Accord is a "gentlemen's agreement" 26 , which may not include legally binding obligations, but does put some pressure, moral if nothing else, on those countries that have affiliated themselves to it and have submitted their pledges to the UNFCCC Secretariat. In other words, the Copenhagen Agreement can be seen as a "political compromise", that stands close, but formally not within the international climate change legal regime.

This last observation leads us to consider whether the Copenhagen Accord, while possibly not a success from an environmental or a strictly legal point of view, may provide some leeway from a political point of view.

\footnotetext{
${ }^{24}$ See an analysis on the legal difficulties arising from the nature of the Copenhagen Accord in RAJAMANI L., Neither Fish nor Fowl, Centre for Policy Research Climate Initiative Seminar 606, February, 2010.

${ }^{25}$ Vienna Convention on the Law of Treaties, 8 ILM 1969, p. 679.

${ }^{26}$ WEMAËRE, "State of play" cit., p. 110,
} 


\section{The political relevance of the Copenhagen Accord}

One can argue that the main weakness of the Kyoto Protocol has been the failure to have on board the - until very recently - biggest emitter of greenhouse gas emissions (the US) and the fact that it did not set any emission reduction obligations for developing countries with emerging economies (countries like China or Brazil).

Obviously, this has nothing to do with the MEA itself, but, on the one hand, with the unwillingness of the previous US administration to commit itself to the Kyoto Protocol, even if under the Clinton administration it had actively participated in the shaping of the Kyoto Protocol, and of its flexible mechanisms in particular. On the other hand, developing countries were not asked to commit to any specific emission reduction obligations in application of the principle of the common but differentiated responsibilities, which is a principle that underpins both the UNFCCC and the Kyoto Protocol ${ }^{27}$. Furthermore, the lack of climate change mitigation commitment by the US and the different action required by developing countries are linked and feed each other. The main argument of the US for not committing itself to binding obligations has always been the absence of similar obligations for countries such as China, India or Brazil ${ }^{28}$. Has the Copenhagen Accord bridged the gap between the US and emerging developing countries?

A preliminary analysis of the Copenhagen Conference seems to indicate that the political deadlock between the US and emerging developing countries may not have been solved completely, but at least it has been addressed. The Copenhagen Accord was negotiated and brokered mainly between the US and the BASIC countries (Brazil, South Africa, India and China). Despite all the doubts that one may have on the environmental integrity and on the legal nature of the Copenhagen Accord, one cannot deny that it is the first time in at least a decade that the US and emerging developing countries have agreed to a framework through which to deal with climate change mitigation and adaptation in the future. In order to tackle

\footnotetext{
${ }^{27}$ UNFCCC, art. 3 and Kyoto Protocol, preamble.

${ }^{28}$ See, for example, the Byrd-Hagel Resolution (US Senate Resolution 98) of 12 June 1997, which stated: "Whereas the Senate strongly believes that the proposals under negotiation, because of the disparity of treatment between Annex I Parties and Developing Countries and the level of required emission reductions, could result in serious harm to the United States economy, including significant job loss, trade and disadvantages, increased energy and consumer costs, or any combination thereof; ..."
} 
climate change efficiently, the international community needs to have the biggest emitters sitting at the same table, and this happened on the last day of the Copenhagen Conference.

The downside of the gentleman's agreement between the US and the BASIC countries is its content. As we have seen, both from an environmental and from a legal perspective, it is not satisfactory. A closer look at the Copenhagen Accord and, in particular, at the pledges that derive from it, shows that the balance between industrialized and developing countries, and also between industrialized countries, lies on thin ice. On the one hand, all climate change mitigation action from developing countries is voluntary and, in some cases, conditional upon international financial and technical assistance ${ }^{29}$, or upon the conclusion of a legally binding agreement in Cancun at $\mathrm{COP}_{1} 6^{30}$. On the other hand, some industrialized countries make their level of climate change mitigation ambition conditional upon neighbor countries' climate action $^{31}$, or upon climate packages in emerging developing countries ${ }^{32}$.

More than the voluntary nature of the obligations, which would not be a problem should there be real political will to tackle climate change, what is worrying is the "conditional" nature of these obligations. The moment one country considers that the variables needed to take action are no longer present, it will feel free to downsize its climate change mitigation action in detriment of the effectiveness of the international climate change regime. In other words, it is very easy to foresee that the ice on which the Copenhagen Accord stands may easily break, since this will happen when even just one key country does not comply with voluntary targets it has set itself, possibly leading to a domino effect because of competitiveness concerns.

In sum, while a first look at the Copenhagen Accord may seem positive from a political point of view since it enables the US and key emerging developing countries, such as China and Brazil, to follow a common path, the conditional nature of the voluntary obligations

\footnotetext{
${ }^{29}$ See Mexico's pledge in Annex III.

${ }^{30}$ See South Africa's pledge in Annex III.

${ }^{31}$ See Canada's pledge in relation to US climate policy in Annex II.

${ }^{32}$ See the EU's position in its pledge in Annex II.
} 
may very quickly undermine any positive outcome arising from the Copenhagen Conference.

\section{CONCLUSIONS: THE COPENHAGEN ACCORD AND THE FRAGMENTATION OF THE INTERNATIONAL CLIMATE CHANGE REGIME}

The Copenhagen Accord has been defined in a number of ways. Lavanya Rajamani has been amongst the most critical in her commentary maintaining that:

“[T]he Copenhagen Accord can plausibly be characterized as 'rotten' not just because it is weak and will not contain climate change in its current form, but also because even in this weak form it faces considerable legal and procedural challenges to its operationalization" 33 .

Daniel Bodansky takes a more pragmatic approach by stating that:

"[A]lthough the Copenhagen Accord has been criticized by some as inadequate or worse, it represents a potentially significant breakthrough... The Copenhagen Accord may well represent the high-water mark of climate change regime for some time to come" 34 .

In this paper on the Copenhagen Accord we position ourselves somewhere in the middle. We do not go so far as to say that it a "rotten" document, but we also do not believe that it can be considered "a significant breakthrough".

We have argued that the Copenhagen Accord can be assessed under environmental, legal and political parameters. Our conclusion is that it clearly fails under the first two parameters, while a preliminary analysis may seem to provide a more positive conclusion if assessed solely from a political point of view.

From an environmental point of view, the Copenhagen Accord fails because, even if pledges were complied with, overall increase in average temperatures will not be limited to 2 degrees. Furthermore, the bottom up approach established in the Copenhagen Accord provides too much flexibility to countries in their climate change mitigation action.

\footnotetext{
${ }^{33}$ RAJAMANI L., note 24 above, p. 26.

${ }^{34}$ BODANSKY D., "The Copenhagen Climate Accord”, ASIL Insight, no 14.3, 2010, p. 4.
} 
From a legal point of view the Copenhagen Accord also fails because the obligations provided for therein are only voluntary and the MRV system moves away from the compliance system present in the Kyoto Protocol. Furthermore, the Copenhagen Accord itself finds itself in a sort of legal limbo, which does not help in understanding to what extent negotiations can rely on it to shape the future of the international climate change regime.

Finally, from a political point of view, while the Copenhagen Accord did bring together key players such as the US and the BASIC countries, that actually were the ones able to broker the document in the last hours of the Copenhagen Conference, a closer look at the Copenhagen Accord leaves one with a different conclusion. The conditional nature of the voluntary obligations provided for therein does not seem to provide solid grounds for a future international climate change regime based on the Copenhagen Accord.

If for all these reasons the Copenhagen Conference can be judged as a disappointment, what should we expect in the run up to COP16 and COP/MOP6 in Cancun in 2010? The Copenhagen Accord will be an important stepping stone for those countries that have affiliated themselves to it, but I am sceptical as to whether it will become the key framework of the future international climate change legal regime.

My impression is that we are moving towards an increasingly fragmented scenario where, in the short term, the two negotiating tracks under the UNFCCC and the Kyoto Protocol will need to find ways to coexist with those negotiations that will have to start in order to make the Copenhagen Accord truly operational, if there is political will to do so.

In the long term, the scenario may become even more complex with key countries becoming more and more uncomfortable with the painstaking process of international negotiations and deciding to pursue bilateral and regional routes to tackle climate change. At the same time, these countries will also start to consider arrangements with other key players (not only States, but business in particular) to advance new carbon markers through sectoral carbon trading and REDD (or REDD similar) mechanisms.

Whether the future international climate change legal regime will be fragmented or not, only time will tell. There is an inherent risk if this occurs, which is to lose sight of the fact that climate change is a "global" phenomenon. Only a strong and common response from 
the international community as a whole can provide a long lasting solution. International climate change negotiations throughout the next two years will show whether the Copenhagen Accord will lead towards a more unitary or more fragmented answer to the climate change challenge.

\section{BIBLIOGRAPHY}

BODANSKY D., "The Copenhagen Climate Accord”, in ASIL Insight, no 14.3, 2010

CAMPINS ERITJA M., FERNÁNDEZ PONS X. and HUICI SANCHO L., "Compliance Mechanisms in the Framework Convention on Climate Change and the Kyoto Protocol", Revue Générale de Droit, no. 34.1, 2004, pp. 51-105

DUBASH N.K., "Copenhagen: Climate of Mistrust", Economic and Political Weekly, no. 52, 2009, pp. 8-11

LEVIN K. and BRADLEY R., "Comparability of Annex I Emission Reduction Pledges," WRI Working Paper, World Resources Institute, Washington DC, p. 2. Accessed on 15/04/10, at http://www.wri.org.

PACHAURI R.K. and RESINGER A. (Eds.), IPCC Fourth Assessment Report, Climate Change 2007 Synthesis Report, Contribution of Working Groups I, II and III to the Fourth Assessment Report of the Intergovernmental Panel on Climate Change, Geneva, 2007. Accessed on 15/04/10, at http://www.ipcc.ch/pdf/assessment-report/ar4/syr/ar4_syr.pdf

RAJAMANI L., Neither Fish nor Fowl, Centre for Policy Research Climate Initiative Seminar 606, February, 2010.

WEMAËRE M., "State of play of the international climate change negotiations: what are the results of the Copenhagen Conference?", Carbon and Climate Law Review, no. 4.1, 2010, pp. 106-111

WEMAËRE M., "State of Play of International Negotiations: On the Road to Copenhagen", Carbon and Climate Law Review, no. 3.4, 2009, pp. 497-502 


\title{
ANNEX I: THE COPENHAGEN ACCORD
}

Advance unedited version

\section{Decision -/CP.15}

The Conference of the Parties,

Takes note of the Copenhagen Accord of 18 December 2009.

\author{
Copenhagen Accord
}

The Heads of State, Heads of Government, Ministers, and other heads of the following delegations present at the United Nations Climate Change Conference 2009 in Copenhagen: [List of Parties]

In pursuit of the ultimate objective of the Convention as stated in its Article 2,

Being guided by the principles and provisions of the Convention,

Noting the results of work done by the two Ad hoc Working Groups,

Endorsing decision x/CP.15 on the Ad hoc Working Group on Long-term Cooperative Action and decision x/CMP.5 that requests the Ad hoc Working Group on Further Commitments of Annex I Parties under the Kyoto Protocol to continue its work,

Have agreed on this Copenhagen Accord which is operational immediately. 
1. We underline that climate change is one of the greatest challenges of our time. We emphasise our strong political will to urgently combat climate change in accordance with the principle of common but differentiated responsibilities and respective capabilities. To achieve the ultimate objective of the Convention to stabilize greenhouse gas concentration in the atmosphere at a level that would prevent dangerous anthropogenic interference with the climate system, we shall, recognizing the scientific view that the increase in global temperature should be below 2 degrees Celsius, on the basis ofequity and in the context of sustainable development, enhance our long-term cooperative action to combat climate change. We recognize the critical impacts of climate change and the potential impacts of response measures on countries particularly vulnerable to its adverse effects and stress the need to establish a comprehensive adaptation programme including international support.

2. We agree that deep cuts in global emissions are required according to science, and as documented by the IPCC Fourth Assessment Report with a view to reduce global emissions so as to hold the increase in global temperature below 2 degrees Celsius, and take action to meet this objective consistent with science and on the basis of equity. We should cooperate in achieving the peaking of global and national emissions as soon as possible, recognizing that the time frame for peaking will be longer in developing countries and bearing in mind that social and economic development and poverty eradication are the first and overriding priorities of developing countries and that a low-emission development strategy is indispensable to sustainable development.

3. Adaptation to the adverse effects of climate change and the potential impacts of response measures is a challenge faced by all countries. Enhanced action and international cooperation on adaptation is urgently required to ensure the implementation of the Convention by enabling and supporting the implementation of adaptation actions aimed at reducing vulnerability and building resilience in developing countries, especially in those that are particularly vulnerable, especially least developed countries, small island developing States and Africa. We agree that developed countries shall provide adequate, predictable and sustainable financial resources, technology and capacity-building to support the implementation of adaptation action in developing countries. 
4. Annex I Parties commit to implement individually or jointly the quantified economy-wide emissions targets for 2020, to be submitted in the format given in Appendix I by Annex I Parties to the secretariat by 31 January 2010 for compilation in an INF document. Annex I Parties that are Party to the Kyoto Protocol will thereby further strengthen the emissions reductions initiated by the Kyoto Protocol. Delivery of reductions and financing by developed countries will be measured, reported and verified in accordance with existing and any further guidelines adopted by the Conference of the Parties, and will ensure that accounting of such targets and finance is rigorous, robust and transparent.

5. Non-Annex I Parties to the Convention will implement mitigation actions, including those to be submitted to the secretariat by non-Annex I Parties in the format given in Appendix II by 31 January 2010, for compilation in an INF document, consistent with Article 4.1 and Article 4.7 and in the context of sustainable development. Least developed countries and small island developing States may undertake actions voluntarily and on the basis of support. Mitigation actions subsequently taken and envisaged by NonAnnex I Parties, including national inventory reports, shall be communicated through national communications consistent with Article 12.1(b) every two years on the basis of guidelines to be adopted by the Conference of the Parties. Those mitigation actions in national communications or otherwise communicated to the Secretariat will be added to the list in appendix II. Mitigation actions taken by Non-Annex I Parties will be subject to their domestic measurement, reporting and verification the result of which will be reported through their national communications every two years. Non-Annex I Parties will communicate information on the implementation of their actions through National Communications, with provisions for international consultations and analysis under clearly defined guidelines that will ensure that national sovereignty is respected. Nationally appropriate mitigation actions seeking international support will be recorded in a registry along with relevant technology, finance and capacity building support. Those actions supported will be added to the list in appendix II. These supported nationally appropriate mitigation actions will be subject to international measurement, reporting and verification in accordance with guidelines adopted by the Conference of the Parties.

6. We recognize the crucial role of reducing emission from deforestation and forest degradation and the need to enhance removals of greenhouse gas emission by forests and 
agree on the need to provide positive incentives to such actions through the immediate establishment of a mechanism including REDD-plus, to enable the mobilization of financial resources from developed countries.

7. We decide to pursue various approaches, including opportunities to use markets, to enhance the cost-effectiveness of, and to promote mitigation actions. Developing countries, especially those with low emitting economies should be provided incentives to continue to develop on a low emission pathway.

8. Scaled up, new and additional, predictable and adequate funding as well as improved access shall be provided to developing countries, in accordance with the relevant provisions of the Convention, to enable and support enhanced action on mitigation, including substantial finance to reduce emissions from deforestation and forest degradation (REDD-plus), adaptation, technology development and transfer and capacity-building, for enhanced implementation of the Convention. The collective commitment by developed countries is to provide new and additional resources, including forestry and investments through international institutions, approaching USD 30 billion for the period 2010 . 2012 with balanced allocation between adaptation and mitigation. Funding for adaptation will be prioritized for the most vulnerable developing countries, such as the least developed countries, small island developing States and Africa. In the context of meaningful mitigation actions and transparency on implementation, developed countries commit to a goal of mobilizing jointly USD 100 billion dollars a year by 2020 to address the needs of developing countries. This funding will come from a wide variety of sources, public and private, bilateral and multilateral, including alternative sources of finance. New multilateral funding for adaptation will be delivered through effective and efficient fund arrangements, with a governance structure providing for equal representation of developed and developing countries. A significant portion of such funding should flow through the Copenhagen Green Climate Fund.

9. To this end, a High Level Panel will be established under the guidance of and accountable to the Conference of the Parties to study the contribution of the potential sources of revenue, including alternative sources of finance, towards meeting this goal. 
10. We decide that the Copenhagen Green Climate Fund shall be established as an operating entity of the financial mechanism of the Convention to support projects, programme, policies and other activities in developing countries related to mitigation including REDD-plus, adaptation, capacity-building, technology development and transfer.

11. In order to enhance action on development and transfer of technology we decide to establish a Technology Mechanism to accelerate technology development and transfer in support of action on adaptation and mitigation that will be guided by a country-driven approach and be based on national circumstances and priorities.

12. We call for an assessment of the implementation of this Accord to be completed by 2015, including in light of the Convention.s ultimate objective. This would include consideration of strengthening the long-term goal referencing various matters presented by the science, including in relation to temperature rises of 1.5 degrees Celsius. 
ANNEX II: QUANTIFIED ECONOMY-WIDE EMISSIONS TARGETS FOR 2020

\begin{tabular}{|c|c|c|}
\hline \multirow[t]{2}{*}{ Annex I Parties } & \multicolumn{2}{|l|}{ Quantified economy-wide emissions targets for 2020} \\
\hline & Emissions reduction in 2020 & Base year \\
\hline Australia & $\begin{array}{l}-5 \% \text { up to }-15 \% \text { or }-25 \% \\
\text { Australia will reduce its greenhouse gas } \\
\text { emissions by } 25 \% \text { on } 2000 \text { levels by } 2020 \text { if } \\
\text { the world agrees to an ambitious global deal } \\
\text { capable of stabilising levels of greenhouse } \\
\text { gases in the atmosphere at } 450 \text { ppm CO2-eq or } \\
\text { lower. Australia will unconditionally reduce } \\
\text { our emissions by } 5 \% \text { below } 2000 \text { levels by } \\
2020 \text {, and by up to } 15 \% \text { by } 2020 \text { if there is a } \\
\text { global agreement which falls short of securing } \\
\text { atmospheric stabilisation at } 450 \text { ppm CO2-eq } \\
\text { and under which major developing economies } \\
\text { commit to substantially restrain emissions and } \\
\text { advanced economies take on commitments } \\
\text { comparable to Australia's. }\end{array}$ & 2000 \\
\hline Canada & $\begin{array}{l}17 \% \text {, to be aligned with the final economy- } \\
\text { wide emissions target of the United States in } \\
\text { enacted legislation. }\end{array}$ & 2005 \\
\hline European Union & $\begin{array}{l}20 \% / 30 \% \\
\text { As part of a global and comprehensive } \\
\text { agreement for the period beyond } 2012 \text {, the EU } \\
\text { reiterates its conditional offer to move to a } 30 \% \\
\text { reduction by } 2020 \text { compared to } 1990 \text { levels, } \\
\text { provided that other developed countries }\end{array}$ & 1990 \\
\hline
\end{tabular}




\begin{tabular}{|c|c|c|}
\hline & $\begin{array}{l}\text { commit themselves to comparable emission } \\
\text { reductions and that developing countries } \\
\text { contribute adequately according to their } \\
\text { responsibilities and respective capabilities. }\end{array}$ & \\
\hline Japan & $\begin{array}{l}25 \% \text { reduction, which is premised on the } \\
\text { establishment of a fair and effective } \\
\text { international framework in which all major } \\
\text { economies participate and on agreement by } \\
\text { those economies on ambitious targets. }\end{array}$ & 1990 \\
\hline New Zealand & $\begin{array}{l}\text { New Zealand is prepared to take on a } \\
\text { responsibility target for greenhouse gas } \\
\text { emissions reductions of between } 10 \text { per cent } \\
\text { and } 20 \text { per cent below } 1990 \text { levels by } 2020 \text {, if } \\
\text { there is a comprehensive global agreement. } \\
\text { This } \\
\text { - the global agreement sets the world on a } \\
\text { pathway to limit temperature rise to not more } \\
\text { than } \\
\text { - developed countries make comparable efforts } \\
\text { to those of } \\
\text { - advanced and major emitting developing } \\
\text { countries take action fully commensurate with } \\
\text { their } \\
\text { - there is an effective set of rules for land use, } \\
\text { land-use change and forestry (LULUCF); and } \\
\text { - there is full recourse to a broad and efficient } \\
\text { international carbon market. }\end{array}$ & 1990 \\
\hline Norway & $\begin{array}{l}30-40 \% \\
\text { As part of a global and comprehensive }\end{array}$ & 1990 \\
\hline
\end{tabular}




\begin{tabular}{|c|c|c|}
\hline & $\begin{array}{l}\text { agreement for the period beyond } 2012 \text { where } \\
\text { major emitting Parties agree on emissions } \\
\text { reductions in line with the } 2 \text { degrees Celsius } \\
\text { target, Norway will move to a level of } 40 \% \\
\text { reduction for } 2020 \text {. }\end{array}$ & \\
\hline Russian Federation & $\begin{array}{l}15 \%-25 \% \\
\text { the range of the GHG emission reductions will } \\
\text { depend on the following conditions: } \\
\text { - Appropriate accounting of the potential of } \\
\text { Russia's forestry in frame of contribution in } \\
\text { meeting the obligations of the anthropogenic } \\
\text { emissions } \\
\text { - Undertaking by all major emitters the legally } \\
\text { binding obligations to reduce anthropogenic } \\
\text { GHG emissions. }\end{array}$ & 1990 \\
\hline $\begin{array}{l}\text { United States of } \\
\text { America }\end{array}$ & $\begin{array}{l}\text { In the range of } 17 \% \text {, in conformity with } \\
\text { anticipated U.S. energy and climate legislation, } \\
\text { recognizing that the final target will be reported } \\
\text { to the Secretariat in light of enacted } \\
\text { legislation. }{ }^{1} \\
{ }^{1} \text { The pathway set forth in pending legislation } \\
\text { would entail a } 30 \% \text { reduction in } 2025 \text { and a } \\
42 \% \text { reduction in } 2030 \text {, in line with the goal to } \\
\text { reduce emissions } 83 \% \text { by } 2050 \text {. }\end{array}$ & 2005 \\
\hline
\end{tabular}




\section{ANNEX III: NATIONALLY APPROPRIATE MITIGATION ACTIONS OF DEVELOPING COUNTRY PARTIES}

\begin{tabular}{|c|c|}
\hline \begin{tabular}{|l|} 
Non-Annex I \\
\end{tabular} & Actions \\
\hline Brazil & $\begin{array}{l}\text { Please note that the envisaged domestic actions as indicated are } \\
\text { voluntary in nature and will be implemented in accordance with } \\
\text { the principles and provisions of the UNFCCC,... } \\
\text { - Reduction in Amazon deforestation } \\
\text { - Reduction in "Cerrado" deforestation } \\
\text { - } \text { Restoration of grazing land } \\
\text { - Integrated crop-livestock system } \\
\text { - No-till farming } \\
\text { - Biological N2 fixaion } \\
\text { - Energy efficiceny } \\
\text { - Increase in the use of biofuels } \\
\text { - Increase in energy supply by hydroelectric power plants } \\
\text { - Alternative energy sources } \\
\text { - Iron \& steel (replace coal from deforestation with coal } \\
\text { from planted forests) } \\
\text { reduction of } 36,1 \% \text { to } 38,9 \% \text { regarding the projected emissions of } \\
\text { Brazil by } 2020 \text {. }\end{array}$ \\
\hline China & $\begin{array}{l}\text { China will endeavor to lower its carbon dioxide emissions per unit } \\
\text { of GDP by } 40-45 \% \text { by } 2020 \text { compared to the } 2005 \text { level, increase } \\
\text { the share of non-fossil fuels in primary energy consumption to }\end{array}$ \\
\hline
\end{tabular}




\begin{tabular}{|c|c|}
\hline & $\begin{array}{l}\text { around } 15 \% \text { by } 2020 \text { and increase forest coverage by } 40 \text { million } \\
\text { hectares and forest stock volume by } 1.3 \text { billion cubic meters by } \\
2020 \text { from the } 2005 \text { levels. } \\
\text { Please note that the above-mentioned autonomous domestic } \\
\text { mitigation actions are voluntary in nature and will be implemented } \\
\text { in accordance with the principles and provisions of the UNFCCC, } \\
\text { in particular Article } 4 \text {, paragraph } 7 \text {. }\end{array}$ \\
\hline India & $\begin{array}{l}\text { India will endeavour to reduce the emissions } 1 \text { intensity of its GDP } \\
\text { by } 20-25 \% \text { by } 2020 \text { in comparison to the } 2005 \text { level. The } \\
\text { emissions from agriculture sector will not form part of the } \\
\text { assessment of emissions intensity. } \\
\text { Please note that the proposed domestic actions are voluntary in } \\
\text { nature and will not have legally binding character. }\end{array}$ \\
\hline Mexico & $\begin{array}{l}\text { Mexico adopted its Special Climate Change Program in } 2009 \\
\text { including a set of nationally appropriate mitigation and adaptation } \\
\text { actions to be undertaken in all relevant sectors. The full } \\
\text { implementation of the Programme will achieve a reduction in total } \\
\text { annual emissions of } 51 \text { million tons of CO2e by 2012, with respect } \\
\text { to the business as usual scenario. } \\
\text { Mexico aims at reducing its GHG emissions up to } 30 \% \text { with } \\
\text { respect to the business as usual scenario by 2020, provided the } \\
\text { provision of adequate financial and technological support from } \\
\text { developed countries as part of a global agreement. }\end{array}$ \\
\hline South Africa & $\begin{array}{l}\text { South Africa reiterates that it will take nationally appropriate } \\
\text { mitigation actions to enable a } 34 \% \text { deviation below the 'Business }\end{array}$ \\
\hline
\end{tabular}




\begin{tabular}{|l|l|}
\hline As Usual' emission growth trajectory by 2020 and a $42 \%$ \\
deviation below the 'Business As Usual' emission growth \\
trajectory by 2025. In accordance with article 4.7 of the \\
Convention, the extent to which this action will be implemented \\
depends on the provisions of financial resources, the transfer of \\
technology and capacity building support by developed countries. \\
Therefore, the above actions requires the finalisation of an \\
ambitious, fair, effective and binding multilateral agreement under \\
the UNFCCC and its Kyoto Protocol at COP 16 and CMP6 in \\
Mexico to enable the delivery of this support.
\end{tabular}

